DOI:10.17951/h.2019.53.2.7-15

\begin{tabular}{lcc}
\hline \multicolumn{1}{c}{ A N N A L E S } \\
UNIVERSITATIS MARIAE CURIE-SKŁODOWSKA \\
LUBLIN - POLONIA \\
VOL. LIII, 2 \\
\hline
\end{tabular}

\author{
KRZYSZTOF BŁOŃSKI \\ krzysztof.blonski@usz.edu.pl \\ University of Szczecin, al. Papieża Jana Pawła II 22A, 70-453 Szczecin, Poland \\ ORCID ID: https://orcid.org/0000-0002-1713-625X
}

JOLANTA WITEK

jwitek@ajp.edu.pl

The Jacob of Paradies University, ul. Teatralna 25, 66-400 Gorzów Wielkopolski, Poland

ORCID ID: https://orcid.org/0000-0002-8120-6494

\title{
Minimalism in consumption
}

Keywords: consumption; minimalism; consumer behaviour

JEL: D11; M30; Z13

How to quote this paper: Błoński, K., \& Witek, J. (2019). Minimalism in consumption. Annales Universitatis Mariae Curie-Skłodowska, sectio H-Oeconomia, Vol. 53, No. 2.

\begin{abstract}
One of the trends in consumer behaviour that has been gradually gaining strength since the beginning of the $21^{\text {st }}$ century is minimalism, also defined as anti-consumerism, voluntary simplicity and deconsumption. These notions are not identical, although, according to research, the conceptual scope is very approximate. Minimalism means deliberately limiting consumption to the rational sizes that result from the natural, individual, physical and mental characteristics of consumers, while emphasising responsible decision-making in this area. The most common expression of processes related to minimalism is mainly the limitations in quantitative and structural consumption. The aim of the article is to present the state of knowledge about minimalism in consumption on the basis of the analysis of the Polish literature on the subject and the results of scientific research. In the case of consumption, minimalism is compared with other concepts and described in terms of the various research fields of consumption. In the case of trends in consumer behaviour, the term is contrasted with deconsumption and voluntary simplicity. It is indicated as part of a lifestyle of sustainable consumption, and occurs when discussing food wastage as
\end{abstract}


well as fashion. It should be noted that the given issues are related to each other, and their separation/ separate treatment results from the adaptation of individual principles and rules by different groups of consumers depending on their own needs.

\section{Introduction}

One of the trends in consumer behaviour that has been gradually gaining strength since the beginning of the $21^{\text {st }}$ century is minimalism, also defined as anti-consumerism, voluntary simplicity (VS) and deconsumption. These notions are not identical, although, according to research, the conceptual scope is very approximate. Minimalism means deliberately limiting consumption to the rational sizes that result from the natural, individual, physical and mental characteristics of consumers, while emphasising responsible decision-making in this area. The most common expression of processes related to minimalism is mainly the limitations in quantitative and structural consumption.

However, the fairly limited extent of this trend means that the critical perception of fast-growing material consumption and consumerism still prevails in the sociological and economic literature of Western Europe. Such concepts are even considered to be a disease of civilisation, the symptoms of which are: the feeling of constant dissatisfaction, fatigue, nervous tension, haste, the feeling of a constant lack of something and the resulting purchases (so-called shopaholism) etc., which results in the states of workaholism, permanent debt to banks, excess of waste (mainly post-consumer), a deterioration in relations with the social environment, etc. As a result of intensive educational campaigns in recent years for a healthy lifestyle, supported by appropriate legislation (mainly from the World Health Organisation and the European Union), the criticism of unrestrained consumption has grown and attempts are being made to rationalise some of its areas, in particular the use of food, housing, medical services, entertainment and recreation. In addition to medical reasons, ecological and ethical arguments play an important role. The VS movement has emerged, which claims that we can live well by reducing resources. The Rhinebeck Institute of New York, which is concerned with social movement research, considers this to be one of the most serious trends of the 1990s. Meanwhile, the Stanford Research Centre estimates the number of Americans who have voluntarily simplified their lives at 10-20 million. The growing disappointment in recent decades, and even negative experiences from possessing an excess of goods, is causing an increasing amount of people to re-evaluate their views, as a result of which consumption is being reduced to the role of an instrument - one of the important conditions of a good life but not its essence or an independent goal. The goal of human life, according to Erich Fromm's optics, is that people should not have (and therefore also consume) riches, but rather have "the richness of being". This process has an important part to play in changing the role of consumption in the value system of many people. 
In terms of Poland, of the many factors influencing the changes in the Polish society, one of the central roles is played by consumption. The social transformations taking place in the consumer society have led to a situation in which consumption has become the most important value, most frequently analysed as a complex phenomenon shaped by the economic and political situation, the dominant value system, and norms and models of behaviour. According to Galbraith, "the consumption impulse was triggered by a system of values that emphasized the productive capacity of the society. The more you produce, the more you need to have in order to maintain prestige and status" (Galbraith, 1973, p. 118). The increase of consumption in Poland is a result of the changes that took place after 1989.

The new social and economic conditions in which households function have allowed them to move from a life based on deprivation, restraint and shortages to a life that allows them to concentrate on materialistic values, pleasure and abundance. This has become a matter of the individual choices of consumers as to what extent they want to be subject to new conditions enabling a wide range of their needs to be met. Referring to Golka's statement that "consumption is to bring happiness to individuals as well as to entire societies" (Golka, 2004, p. 27), it is necessary to recognise the aspirations of households and contemporary value systems, which may constitute a common way of manifesting human identity through consumption. New values related to consumption determine the setting of life goals and consumer aspirations and are the basic criterion of the choices made. In light of this, meeting only the basic needs for some consumers does not seem to satisfy them. As Krajewski notes, "in today's world, it is consumption that takes over the functions of the basic instrument for creating and expressing human personality" (Krajewski, 1997), and this does not omit any aspect of human life. It appears in family and social relations, it is present in the cultural and custom sphere, and it is an inseparable element of everyday life. The importance of consumption and the universality of the use of its functions by man can be proven by the fact that consumption becomes an opportunity to define oneself through the possession of a specific set of material things, as well as the use of specific consumer services. As Veblen notes, "public manifestations of consumption often serve the purpose of demonstrating the status - the place occupied in the social structure, and at least in the income hierarchy" (Veblen, 1971, p. 42). The characteristics of the possessed things make it possible to shape opinions not only about financial capabilities but also about the place occupied in the social hierarchy. Moreover, the ability to use a wide range of consumer services and the possession of material goods has a significant impact on the sense of happiness and security, or may be the cause of sadness and frustration when the possibilities to participate in the desired sphere of consumption are limited.

Nowadays, every person is a consumer of various types of goods and services, but the problem begins when shortages in consumption constitute the social exclusion of a person or when consumption becomes the main purpose of life for the individual. The second theme concerns a situation whereby concern for the improvement of 
material conditions is the only area of human activity, adopts a one-sidedly deformed hierarchy of values, when one wants to build one's own social position through the prism of material values, and at the same time, according to these material criteria, the "value" of the other person is assessed (Bendyk, 2011). Mass consumption in highly developed countries has, in many cases, led to over-consumption, i.e. consumption that is excessive and not justified on the basis of biological or socio-cultural reasons.

With this in mind, the aim of the article is to present the state of knowledge about minimalism in consumption on the basis of the analysis of the Polish literature on the subject and the results of scientific research. The aim is to be a point of reference for future research in order to broaden the scope of the research conducted so far in various research centres, and enable special attention to be paid to the impact of the value system on the shaping of minimalism in consumption, as well as enable the effect of social imitation on the development of this trend to be considered.

\section{Minimalism in consumption - review of literature and research results}

Minimalism ${ }^{1}$ can be considered both in terms of quantity and quality. The former consists of limiting the state of possession; getting rid of excess things from the space surrounding a given person. It means leaving only things that are the most functional and practical. From the qualitative point of view, the considerations lead to the purchasing of more durable items with a longer expiry date and avoiding the purchase and consumption of many disposable products. The issue of quality is not only limited to materials, packaging and workmanship but also to a better quality of use and experience that accompanies it. As a result, it is possible to indicate that quality in the material dimension translates into a subjective quality of life (Kramarczyk, 2015, pp. 276-277).

Skowrońska proposes another examination of the issues of minimalism, which is characterised by examining it from the following perspectives: identity, aesthetic and social bond type characteristics. The author points out that a frequent element of minimalist identity is anti-consumptionism and concentration on the moral aspect of the fight against overproduction, criticism of wastage and disagreement over consumption as a driving force of the economy (Skowrońska, 2013, p. 91). The second perspective - aesthetic - results from the practical application of the principles of minimalism in life. In this case, it is based on simplicity, cohesion and anti-decorative

\footnotetext{
1 As Dopierała (2014, p. 215; 2017, p. 67) indicates, minimalism can be defined as a lifestyle, ideology, way of life, doctrine, worldview or fashion. The books used by minimalists include, among others, the following: D. Loreau, Sztuka prostoty (2011); Idem, Sztuka minimalizmu (2015); Idem, Sztuka umiaru (2011); L. Babauta, Minimalizm (2013); F. Sasaki, Pożegnanie z nadmiarem: minimalizm japoński (2015); K. Kędzierska, Chcieć mniej. Minimalizm w praktyce (2016); F. Jay, Minimalizm daje radość (2016). Attention should also be paid to the large number of blogs addressing this subject on the Internet (for example: simplicite.pl, prostyblog.com, minimalplan.com, drogadominimalizmu.pl, wystarczy-mniej.blogspot.com).
} 
qualities, while the colour scheme is reduced to black, white, beige and grey (p. 95). The last perspective distinguished (the issue of social bonds) is the result of a change in relations with things, which translates into a change in relations with people. Here, we can talk about a change in the shape of these bonds.

Minimalism is based on the modern types of bond and is mainly based on:

- the variety of relationships concluded by choice rather than necessity;

- mobility, where we assume that in every situation there will be a person with whom we will establish relations, who will help us;

- openness to the world and not the home/family/closed system (Skowrońska, 2013, p. 96).

In the case of consumption, the term is compared with other concepts and described in the various research fields of consumption. In the case of trends in consumer behaviour, the term is contrasted with deconsumption and VS. It is indicated as one of the lifestyles of sustainable consumption, and occurs when discussing food wastage (eco-minimalism) as well as fashion. It should be noted the given issues are related to each other, and their separation/separate treatment results from the adaptation of individual principles and rules by different groups of consumers depending on their own needs.

Deconsumption is presented in the literature as an alternative trend to consumerism (Bylok, 2016, p. 63). Taking into account the different ways of defining this concept (e.g. Bywalec \& Rudnicki, 2002, p. 143; Szul, 2012, p. 318), it can be assumed that deconsumption is related to limiting the current excessive consumption for various reasons (e.g. economic crisis, lifestyle changes, increased uncertainty, greater awareness of responsibility and an ethical approach to consumption) (Bylok, 2016, p. 63). The dimensions of deconsumption processes are: limitations in the consumption of a quantitative and structural nature; changes in the consumption of a qualitative nature; a reduction of consumption in the material sphere in favour of the growth of services in consumption; and the rationalisation of consumption and consumer behaviour (Woś, 2003, p. 99; Zalega, 2013, p. 4). According to Szul, minimalism is the basis for deconsumption, guaranteeing spiritual individual human development (Szul, 2012, p. 320). This view is reflected in the results of qualitative research conducted by Wilczak $(2016)^{2}$. The author identified five different levels, describing the nature and extent of involvement in deconsumption. The results of the research indicate the existence of the process character of the deconsumption attitudes and behaviours evolution. Consumers move along a specific continuum defined by the boundaries: fascination with the idea - lifestyle (Wilczak, 2016, p. 391). It should be noted that one can find publications where minimalism is treated as a contraposition

2 Qualitative research carried out with the use of an in-depth individual interview and ethnographic technique. The survey participants were recruited from among local pro-ecological activists and persons participating in events and activities demonstrating interest in conscious consumption. Participation in the survey was expressed by 22 persons. 
of consumerism and is presented as an expression of freedom and conscious life, eliminating from it what is unnecessary (Wąż-Bigos, 2017, p. 161).

Deconsumption can take various forms. One of these is the movement for limiting consumption, e.g. VS in consumption, against which minimalism is juxtaposed (Grzega \& Kieżel, 2017, p. 45). The VS movement was created in the 1980s and the basis for it was the publication of the $19^{\text {th }}$-century writer and philosopher Henry David Thoreau entitled Walden; or, Life in the Woods (2010). VS is defined as the autonomous choice of the individual in terms of limiting spending, with attention paid to intangible values such as sense of meaning and life satisfaction (Ziemkowski, 2007 after Szul, 2012, pp. 319-320). According to Mularczyk-Meyer (2014, pp. 15-17), both indicated concepts have much in common but are not identical; they complement each other and both will be necessary for the person ordering their physical and personal space ${ }^{3}$.

Another form of deconsumption is sustainable consumption (eco-consumption, ecological consumption), which consists in the deliberate efforts of individuals to minimise the adverse effects resulting from the consumption of consumer and investment goods and services through the rationalisation and exploitation of production factors (resources) and the reduction of post-production and post-consumer waste production (Zalega, 2013, p. 5). Eco-consumption results in three consumer trends: conscious consumption, cooperating consumption and freeganism. Conscious consumption (ethical consumption, responsible consumption) is understood to mean the consumer making choices on the basis of knowledge of the social, ecological and political consequences (Zalega, 2013, p. 5). The role of minimalism in conscious consumption can be defined as a strategy of implementing conscious consumption in everyday life (Kramarczyk, 2015, p. 270).

Conclusions drawn from Kramarczyk's research ${ }^{4}$ (2015) indicate that the implementation of conscious consumption in the form of life slowdown and everyday minimalism is a long-term and multistage process. According to the author, this results from the following facts. The changes observed by the respondents concerned not only material things but also the "spiritual", psychological and social sphere. Moreover, the transition from the state of excessive possession to minimalism was not easy and pleasant, as it was connected with the need to undergo physical effort and change one's previous customs and habits. An additional issue was the initial lack of understanding on the part of certain family members or friends to taking such actions. The analysis of the collected material also allowed the author to draw the conclusion that minimalism translates not only into different aspects of everyday

3 "Voluntary simplicity assumes a modest life in material terms, but rich in emotional, intellectual and spiritual spheres. (...) Minimalism emphasizes not only modesty, but also the quantitative aspect".

4 Research conducted by means of narrative interviews (15 persons). The selection of individuals for the research was based on auto-identification (defining oneself in the category of being a minimalist) and the snowball method. According to the data provided by the author, the participants of the interviews were mainly bloggers who run Internet blogs concerning the idea of slow living, minimalism and mindfulness. 
existence but also helps in making decisions (e.g. reduces the number of alternatives) or introduces elements of prudence and reflection (e.g. in planning expenses). Apart from practical examples of the implementation of minimalism in her life, the author also defined a set of factors determining the consumer choices made by respondents the minimalists. These were: sufficient time to make a decision, freedom of choice, maintaining balance in the scope of possessions, product quality and supporting local activities (Kramarczyk, 2015, pp. 278-282).

Minimalism as a lifestyle is presented and described in the publication Stać się pustym oznacza stać się bogatym - minimalizm jako (nowy $i$ utopijny?) styl zycia (Dopierała, 2014, pp. 215-229). Using the typology of lifestyles proposed by Siciński (1976, pp. 85-86), the author categorises minimalism in the following types: searching for a way of life, orientation towards certain values and orientation towards actions aiming at the implementation of change (Dopierała, 2014, p. 216). In the further analysis of the selected items promoting minimalism, she maintains that it reflects almost all characteristics of contemporary times. She points to the reflectiveness of social practices, flexibility of individuals' attitudes, individualism or de-traditionalization. In conclusion, she states that minimalism is an example of orientation towards postmodern values and, among others, the following are important aspects of it: a good life, identity development, self-realisation, authenticity and satisfying interpersonal relations (Dopierała, 2014, p. 224).

\section{Conclusions}

Contemporary consumption - mass, common, generally available - is most often analysed as a complex social, cultural and economic phenomenon shaped by the economic and political situation, and the dominant system of values, norms and models of behaviour. Recognising or reconstructing these factors is important inasmuch as they are nowadays a common way of manifesting human identity. While modernist concepts assume the functioning of an industrial society based on the principle that socioeconomic classes determine the social order and lifestyle, the assumptions of postmodernism emphasise the existence of a post-industrial society, striking out the previous identity designators.

The growing criticism of unrestrained consumption in the United States is not a completely new phenomenon. Puritanism put an emphasis on saving. Quakers propagated the idea of equality between people. Philosophers, writers and poets - Emerson, Thoreau, Whitman and Melville - spoke in the anti-materialist spirit in the $19^{\text {th }}$ century. Warnings stemming from the world of science, as well as from other sources, caused the phenomenon of minimalism, or deconsumption - i.e. the conscious limitation of consumption to rational sizes, resulting from the natural, individual, physical and psychological features of the consumer - to appear in some wealthy people's circles. It may be assumed that this phenomenon will increase in 
strength and that in the near future, these processes will involve a wider circle of societies of highly and medium developed countries, such as Poland.

The premise of such predictions may be to draw attention to the change in symbols of social status. Since the lack of time has reached a level of saturation and the eight-hour sleep has become a symbol of the "higher class", no longer is being overworked to prove one's "importance" a symbol of social position, because it is too easy to be rushed: running from one job to another, exhausted and sleepless. Now we can distinguish ourselves by the amount of "free time to show". The observation of consumer behaviour also shows that consumers are often more interested in the aura of consumption than in the products themselves. Hence, campaigns conducted by the VS Movement for rational market and consumer behaviour, such as Car Free Day, Week Without TV, Non-Purchase Day, etc., are exploring the topic and awakening consumer interest in it.

\section{References}

Babauta, L. (2013). Minimalizm. Gliwice: Wydawnictwo Złote Myśli.

Bendyk, E. (2011). Jakie siły i procesy ukształtują przyszłość? Polityka, http://www.polityka.pl/rynek/ ekonomia/1513014,2,jakie-sily-i-procesy-uksztaltuja-przyszlosc.read\#ixzz1 irHSKgWm [access: 10.02.2019].

Bylok, F. (2016). Meandry konsumpcji we współczesnym społeczeństwie: konsumpcjonizm versus de konsumpcja. Annales. Etyka w życiu gospodarczym, 19(1).

Bywalec, Cz., \& Rudnicki, L. (2002). Konsumpcja. Warszawa: PWE.

Dopierała, R. (2014). „Stać się pustym oznacza stać się bogatym”- minimalizm jako (nowy i utopijny?) styl życia. In: D. Kotuła, A. Piórkowska, A. Poterała (red.), Narracje postkryzysowe w humanistyce. Olsztyn: Uniwersytet Warmińsko-Mazurski.

Dopierała, R. (2017). Minimalism - a new mode of consumption? Przeglad Socjologiczny, 66(4).

Galbraith, J.K. (1973). Spoteczeństwo dobrobytu, państwo przemystowe. Warszawa: PIW.

Golka, M. (red.) (2004). W cywilizacji konsumpcyjnej. Poznań: Wydawnictwo Naukowe UAM.

Grzega, U., \& Kieżel, E. (2017). Trendy w zachowaniach konsumentów. In: M. Bartosik-Purgat (red.), Zachowania konsumentów. Globalizacja, nowe technologie, aktualne trendy, otoczenie społeczno-kulturowe. Warszawa: Wydawnictwo Naukowe PWN.

Jay, F. (2016). Minimalizm daje radość. Warszawa: Wydawnictwo Muza.

Kędzierska, K. (2016). Chcieć mniej. Minimalizm w praktyce. Kraków: Wydawnictwo Znak.

Krajewski, M. (1997). Konsumpcja i współczesność. O pewnej perspektywie rozumienia świata współczesnego. Kultura i Spoleczeństwo, 3.

Kramarczyk, J. (2015). Mieć czy być? Minimalizm jako przykład świadomej konsumpcji w świetle badań własnych. Prace Naukowe Uniwersytetu Ekonomicznego we Wrockawiu, 414.

Loreau, D. (2011). Sztuka umiaru. Warszawa: Wydawnictwo Czarna Owca.

Loreau, D. (2015). Sztuka minimalizmu. Warszawa: Wydawnictwo Czarna Owca.

Loreau, D. (2012). Sztuka prostoty. Warszawa: Wydawnictwo Czarna Owca.

Mularczyk-Meyer, A. (2014). Minimalizm po polsku, czyli jak uczynić życie prostszym. Sękowa: Black Publishing.

Sasaki, F. (2015). Pożegnanie z nadmiarem: minimalizm japoński. Warszawa: Wydawnictwo Burda Media Polska. 
Pobrane z czasopisma Annales H - Oeconomia http://oeconomia.annales.umcs.pl

Data: 26/04/2023 16:24:25

MINIMALISM IN CONSUMPTION

Siciński, A. (1976). Styl życia - problemy pojęciowe i teoretyczne. In: A. Siciński (red.), Styl życia. Koncepcje i propozycje. Warszawa: PWN.

Skowrońska, M. (2013). Minimalizm i chomikowanie: jak radzić sobie z nadmiarem przedmiotów. Kultura Wspótczesna, 1.

Szul, E. (2012). Dekonsumpcja - moda czy sposób na kryzys. Nierówności Społeczne a Wzrost Gospodarczy, 24.

Thoreau, H.D. (2010). Walden, czyli życie w lesie. Poznań: Rebis.

Veblen, T. (1971). Teoria klasy próżniaczej. Warszawa: PWN.

Wąż-Bigos, P. (2017). Minimalizm życiowy - umiar i substytut zdrowego rozsądku we współczesnym społeczeństwie konsumpcyjnym. Logos i Ethos, 45.

Wilczak, A. (2016). Dekonsumpcja jako przejaw odpowiedzialnej postawy i styl życia konsumenta w świetle analizy jakościowej. Handel Wewnętrzny, 3.

Woś, J. (2003). Zachowania konsumenckie - teoria i praktyka. Poznań: Wydawnictwo AE.

Zalega, T. (2013). Nowe trendy i makrotrendy w zachowaniach konsumenckich gospodarstw domowych w XXI w. Konsumpcja i Rozwój, 2.

Ziemkowski, M. (2007). Grypa prosto z dobrobytu. Charaktery, 6 . 